TRIP REPORT

ASTRONUCLEAR LABORATORY

Security Classification: Unclassified

Distribution:
Library $(2) \longleftarrow$
E. L. Layland
L. H. Cooper
H. J. Fix
R. R. Baklarz
J. W. French
E. M. Duran
D. C. Goldberg
J. W. Fisch
A. N. Holden
E. L. Layland
E. M. McKee

WANL-TR-6626

Author(s): W. F. Brizes/D. G. Miller

Date: April 28, 1971

Trip to: WNCO

Date of Trip: April 27, 1971

\title{
PURPOSE OF TRIP
}

1. To select Coated Composite Central Elements for use as friction specimen on TIS 088.2.

2. Discuss radiography for non-destructive examination of $\mathrm{ZrC}$ billets.

3. Examine drawings and discuss surplus coating furnace for possible installation at Large as hydrogen leaching furnace to remove carbon from low density $\mathrm{ZrC}$.

\section{PERSONS PRESENT}

$\frac{\text { WANL }}{\text { W. F. Brizes }}$
D. G. Miller

\author{
WNCO \\ G. R. Kilp \\ E. L. Kochka \\ R. E. Lowder \\ A. J. Pereira
}

\section{SUMMARY}

Mr. E. L. Kochka set aside four central elements (2 lots) and 1-19 hole, non-fueled elements for use as coated composite fuel material for friction test specimens. Coated composite elements for property tests have been sent to WANL.

The coatings were described as representative $\mathrm{ZrC}$ on $\mathrm{ZrC} /$ graphite composite by the low temperature GEM process. Examination disclosed a satin grey surface of $\mathrm{ZrC}$ which was relatively smooth to the touch at all but the cold end. A yellow discoloration appeared over the last 4 inches of element at the hot end. Cracks were observed over large areas on two of the four elements.

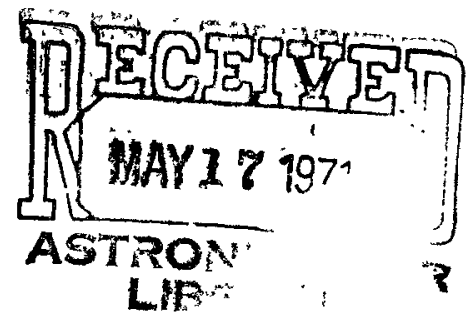




\section{DISCLAIMER}

This report was prepared as an account of work sponsored by an agency of the United States Government. Neither the United States Government nor any agency Thereof, nor any of their employees, makes any warranty, express or implied, or assumes any legal liability or responsibility for the accuracy, completeness, or usefulness of any information, apparatus, product, or process disclosed, or represents that its use would not infringe privately owned rights. Reference herein to any specific commercial product, process, or service by trade name, trademark, manufacturer, or otherwise does not necessarily constitute or imply its endorsement, recommendation, or favoring by the United States Government or any agency thereof. The views and opinions of authors expressed herein do not necessarily state or reflect those of the United States Government or any agency thereof. 


\section{DISCLAIMER}

Portions of this document may be illegible in electronic image products. Images are produced from the best available original document. 
Observations under a binocular microscope of undefined magnification indicated a surface condition of projections and pits which extended the full length of the elements. The concentration of surface defects decreased from the cold to the hot end. A very rough surface gradvally smoothed in the direction of the hot end. The projections and pits did persist on the smoothest surfaces observed at the hot end.

Friction values from TIS 088.2 are expected to reflect the surface condition of the elements as coated. A mechanism of mechanical interlocking of projections with pits and/or gouging with extensive wear could alter test results appreciably. Coefficients of friction, therefore, should be correlated with element location and some attempt must be made to measure a standard surface condition for comparative results.

Radiographs of composite elements were reviewed to compare the homogeneity of extruded $\mathrm{ZrC}$ plus graphite mixtures with hot pressed material being developed for the core periphery. Nineteen hole elements appeared uniform, but, because of the large number of holes, interpretation was difficult. A few spaghetti type elements were examined. They had small defects and a few cracks, but the matrix appeared uniform. It was requested that a few sections of an uncoated composite central element be radiographed and examined.

The need for a $\mathrm{H}_{2}$ leaching furnace was discussed. WNCO furnaces are, in general, graphite furnaces and would require extensive modification before they could be operated in a $\mathrm{H}_{2}$ atmosphere. It was suggested that a smaller furnace, hot zone 10 inch in diameter by 16 inches high, could be modified to run in $\mathrm{H}_{2}$ at $2300^{\circ} \mathrm{C}$. This furnace was purchased for coating work. The furnace has never been uncrated and is at Sussite. The vacuum system and power supply $(930$ cycle $150 \mathrm{Kw}$ ) is also at Sussite. The furnace can be operated continuously by moving the retort into a cooling chamber and then placing another loaded retort into the hot zone by use of a track and ram system. The furnace could be simplified for a batch process, if desired. Blueprints and operational manual for the furnace are at WANL. If there is interest in this furnace, a trip to Sussite is recommended. 